\title{
TO WHAT EXTENT ARE JOKES REACTIONAL? (BASED ON A JOKE CYCLE ABOUT YURY LUZHKOV'S DISMISSAL)
}

\author{
Anastasiya Astapova
}

\begin{abstract}
The article concentrates on jokes that appeared immediately after the dismissal of Yury Luzhkov, Mayor of Moscow, in 2010. As soon as he was fired after eighteen years in the same position of mayor, the Internet was flooded with jokes about his dismissal as well as numerous discussions on internet forums and blogs. I collected the jokes as well as opinions from the discussions, categorised them by their themes, and tried to understand how these two phenomena (jokes and discussions on the Internet) correlate with each other, in order to understand whether the axiom that folklore is a mirror of society is true.
\end{abstract}

Keywords: Yury Luzhkov, (internet) humour, topical jokes, political jokes, reflection of social life in folklore

It seems to be true that whenever something important happens in the world around us, it is immediately manifested in folklore. One of the most 'responsive' genres of folklore is obviously jokes. No wonder that in the 1980s several folklorists turned to the study of such reflections in jokes. For example, some articles concentrated on the jokes that appeared immediately after the disaster of the space shuttle Challenger (Simons 1986; Smyth 1986; Oring 1987).

Contemporary scholarship acknowledges such 'reactional' jokes; for instance, Liisi Laineste focuses on what she calls topical jokes from the point of view of their cognitive function. She takes into consideration mainly the jokes about the terrorist attack in the USA in September 2001, and mass alcohol poisoning in Estonia (Laineste 2008). Similar topics are discussed by Alexandra Arkhipova in her articles dedicated to the jokes about Vladimir Putin, including those which appeared as a reaction to the so-called 'Snow Revolution' in winter 2011-2012 (Arkhipova 2009, 2012). Unlike the aforesaid authors, she uses statistical methods for the analysis of the topical jokes and makes a conclusion about the popularity of the new form of the joke that parodies speech genres.

Nevertheless, many topical joke cycles have been neglected by scholars and forgotten by joke tellers. It would thus be of great interest to learn about how 
and why these joke cycles appear and to what exactly they in fact react. The aim of the present paper is to evaluate this phenomenon through a sample of Russian political jokes, which showed up as soon as Mayor of Moscow Yury Luzhkov was dismissed.

It is important to mention that the jokes under consideration here can also be regarded as political. Research into political jokes in European and American scholarship is quite abundant, as is reflected both in individual articles and whole monographs, or compilations of articles (many sources are enumerated by Aleksandra Arhipova in Anekdot v zarubezhnykh issledovaniiakh XX veka [Arkhipova 2001]). In Russian scholarship this type of joke has been largely ignored not because of any scholar's fault, but because during the Soviet period jokes, especially those of political character, were forbidden not only to study, but even to tell. Nevertheless, the beginning of the study seems to be very promising as there are already examples of high-quality works on political jokes (Shmeleva \& Shmelev 2001; Arkhipova \& Mel'nichenko 2008; Arkhipova 2009; Alekseevskii 2010).

\section{JOKES ABOUT YURY LUZHKOV: BACKGROUND}

Before moving to the jokes, it would be worthwhile to describe the person about whom these jokes were actually made.

Yury Mikhaylovich Luzhkov (born on September 21, 1936) is a Russian politician who served as Mayor of Moscow from 1992 to 2010. He became famous because of the large construction projects in the city (including the building of a new financial district). His second wife, Elena Baturina, is a Russian businesswoman, and Russia's only female billionaire (she became a billionaire during her husband's mayorship, which became the reason why people criticized the mayor).

Luzhkov frequently appeared in public at different festivals and celebrations, and was an enthusiastic promoter of the city. He was critical of homosexuality and issued several bans on the Moscow Pride Parade.

Moscow under Luzhkov kept the Soviet practice of requiring a notice of the permanent living place ('propiska'), as the government wanted to limit uncontrolled migration and homelessness, although the process of registration is very bureaucratic.

Other points of criticism concerned with Luzhkov were ecology spoilt by the great number of automobiles, high corruption rate, bad artistic flair of the mayor mentioned by many artists, which obviously influenced new architecture, and preferences for the dubious works of art by sculptor Zurab Tsereteli and 
painter Alexander Shilov; finally, the authorship of the programme according to which precipitation had to be redistributed to diminish the expenses of cleaning Moscow streets from snow.

Luzhkov is fond of football, horse-riding, tennis, and bee-keeping. His image is strongly connected with the cap he usually wears.

At the end of August 2010, after 18 years of Luzhkov's rule, rumours concerning his dismissal started to spread. None of these rumours were confirmed by the government. Later on, in September, the central governmentally-controlled TV channels showed several documentaries criticizing the politics of Luzhkov, especially the way he handled the 2010 fires around Moscow; also, the mayor and his wife were accused of corruption. He was dismissed by President Dmitry Medvedev at the end of September (after returning from a holiday in Austria) with the official explanation "loss of confidence".

\section{REACTION TO THE DISMISSAL}

People reacted to the event immediately. This reaction on the Internet was mainly expressed in the two following forms:

\section{Jokes.}

It is interesting to follow the jokes about Luzhkov that appeared on the particular website www.babedra.ru, which actually provides about twenty 'fresh political jokes' every month.

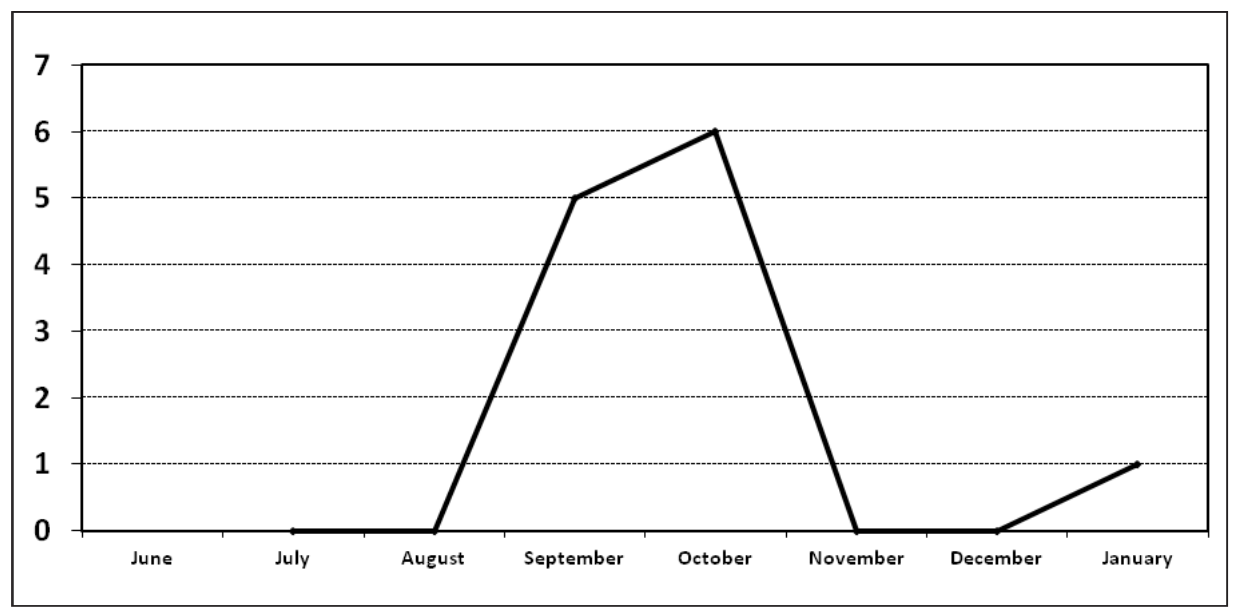

Figure 1. The number of jokes about Luzhkov in 2010 on www.babedra.ru. 
Obviously, Luzhkov became a really popular butt of the jokes in September and October 2010, exactly when he was dismissed. However, it was not only joke websites that enjoyed the outbreak of jokes about Luzhkov at the same time. For example, the thread discussing funny items about Luzhkov (Rzhaki pro Luzhka) appeared on the website www.forum.littleone.ru on September 30, 2010. It included not only jokes, but also demotivators, humorous poems and other genres.

2. Forum discussions.

Another form of reaction was reflected in comments on the situation, which could be found in forums, blogs, and social networking services.

Based on the observations about the simultaneous increase of both jokes and internet discussions about Luzhkov, I argue that these two forms of reaction - jokes and discussions - are definitely closely connected and deserve further consideration and comparison.

\section{METHODS OF RESEARCH AND SOURCES}

Since it has been generally admitted that folklore is the reflection of social life, the two sources described - jokes and discussions - provide a valuable opportunity to challenge this axiom by comparing them. For this purpose, two corpora of data had to be compiled: discussions and jokes. It is important to note that the data were collected in February 2011, five months after Luzhkov's dismissal, when the opinions as well as the jokes were very 'fresh'.

\section{Corpus 1. Discussions}

To consider the discussions, I chose the following sources:

1. The thread 'Why all TV channels suddenly started to flay Luzhkov?' on www. forum.littleone.ru (appeared after the first TV programmes began criticizing Luzhkov, just a few days before the official dismissal; contained 95 messages).

2. 'Is Luzhkov interesting for anybody here?' on www.forum.littleone.ru (appeared right after Luzhkov's official dismissal; contained 212 messages).

\section{Livejournal.com}

The first one hundred results in search of 'Luzhkov' on www.livejournal.com.

\section{Twitter.com}

The first one hundred results in search of 'Luzhkov' on www.twitter.com. 
The choice of the sources is not random. The forum where the first two threads appeared is not specifically political: it was created first as a forum for Saint Petersburg parents to discuss problems connected with pregnancy, upbringing, education, schools, and other questions associated with children, but it has gradually broadened, and now it also contains threads about weddings, shopping, automobiles, jobs, art, cooking and so on, as well as politics. Probably, the composition of the forum users remains mainly female, but as the forum has expanded, many more male users have joined in as well, especially as compared to the beginning of the website.

Even though the forum is meant to be for Saint Petersburg, not Moscow parents, the Moscow mayor was discussed there. This made me think that the users on this forum would touch upon more serious topics, the ones that might also be reflected in the jokes, while Moscow forums probably also have discussions on minor and less important local events.

Concerning Twitter and LiveJournal, these sources are among the most popular social networking services. Thus I managed to get data from both the wide-spread and well-known sources as well as less popular (not political) sources, which have different aims and main themes for discussions.

With the help of the data I tried to follow how the users estimated Luzhkov's activities, and which attributes of his personality as well as which prominent events of his rule were mentioned. Thus I categorized the theme of each message posted on the topic (for example, "Luzhkov is a thief").

Sometimes the posts were repeated, for example, on LiveJournal: in this case both/all items are taken into consideration and included among the data because it means that this particular topic is interesting for the users as it is exploited by more than one user.

On the other hand, sometimes one and the same post indicates several themes. For instance, one and the same message could claim that Luzhkov deserves criminal liability, and that his wife is a rich woman. In this case all the themes are taken into account. Thus, even though only the first 100 results of search for 'Luzhkov' were included in the research, the considered posts sometimes discussed more than one theme each - that is why all in all I got 126 categorisations.

At the same time a lot of messages on the forum contained only emoticons, e.g. smileys (as some discussions were humorous); that is why, for example, from the first thread which contained 95 messages only 66 themes were extracted.

As a whole, I had 429 opinion themes extracted from the messages in the discussions I read: 66 and 117 from the two www.forum.littleone.ru threads, 120 from LiveJournal and 126 from Twitter. 


\begin{tabular}{|c|c|c|c|c|c|}
\hline & 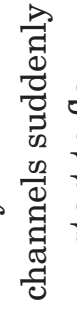 & 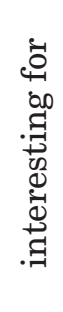 & 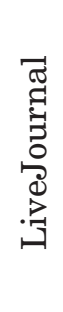 & 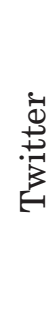 & $\stackrel{\vec{\pi}}{\stackrel{0}{0}}$ \\
\hline $\begin{array}{l}\text { Refusal to take part in the Day of } \\
\text { Anger }\end{array}$ & & & 8 & 47 & 55 \\
\hline $\begin{array}{l}\mathrm{L} \text { was not favoured by the government } \\
\text { any more (there was a conflict) }\end{array}$ & 17 & 8 & 6 & 4 & 35 \\
\hline L compared with Matvienko & 4 & 22 & & & 26 \\
\hline $\mathrm{L}$ is a thief who stole a lot & & 12 & 10 & 2 & 24 \\
\hline $\begin{array}{l}\text { Ideas about who will become the new } \\
\text { mayor }\end{array}$ & & 22 & & & 22 \\
\hline $\begin{array}{l}\text { Application for the British residence } \\
\text { permit }\end{array}$ & & & 4 & 17 & 21 \\
\hline $\begin{array}{l}\text { Moscow architecture (spoilt, new, } \\
\text { destroyed) }\end{array}$ & & 4 & 7 & 10 & 21 \\
\hline $\begin{array}{l}\text { Application for the Latvian residence } \\
\text { permit }\end{array}$ & & & 10 & 10 & 20 \\
\hline Bee-keeping & 7 & 5 & 1 & 5 & 18 \\
\hline $\begin{array}{l}\mathrm{L} \text { as a very rich man ( } \mathrm{L} \text { is rich enough } \\
\text { to live well in the future) }\end{array}$ & 12 & 3 & & & 15 \\
\hline Sobyanin & & & 9 & 6 & 15 \\
\hline Criminal liability of $\mathrm{L}$ & & 2 & 8 & 4 & 14 \\
\hline Elena Baturina & 3 & 5 & 5 & & 13 \\
\hline $\begin{array}{l}\text { Mass media broadcasts were ordered } \\
\text { by the government }\end{array}$ & 13 & & & & 13 \\
\hline Random remarks & & & 11 & 1 & 12 \\
\hline Positive opinions about L & 5 & 6 & & & 11 \\
\hline $\begin{array}{l}\text { Talks about 'otreshenie' } \\
\text { (impeachment), loss of confidence }\end{array}$ & & 5 & 3 & & 8 \\
\hline The problem of traffic jams & & 3 & 5 & & 8 \\
\hline $\begin{array}{l}\text { The dismissal is just a show-off before } \\
\text { the upcoming election }\end{array}$ & & 7 & & & 7 \\
\hline Building of new roads & & 2 & 1 & 3 & 6 \\
\hline $\begin{array}{l}\text { High-tech toilets designed by L and } \\
\text { called off by Sobyanin }\end{array}$ & & & 4 & 1 & 5 \\
\hline
\end{tabular}




\begin{tabular}{|c|c|c|c|c|c|}
\hline L's attitude towards homosexuals & & 3 & & 2 & $\mathbf{5}$ \\
\hline $\begin{array}{l}\text { New ways of cleaning snow in Moscow } \\
\text { by Sobyanin }\end{array}$ & & & 5 & & 5 \\
\hline $\begin{array}{l}\text { Common people will never know the } \\
\text { reasons of the conflict }\end{array}$ & 1 & & 3 & & 4 \\
\hline L's old age, time for him to retire & 2 & & & 2 & 4 \\
\hline L and Ukraine & & & 3 & 1 & 4 \\
\hline $\begin{array}{l}\text { L compared to Berezovsky and } \\
\text { Hodorkovsky }\end{array}$ & & & & 4 & 4 \\
\hline \begin{tabular}{|l|} 
Neutral reference \\
\end{tabular} & 2 & 2 & & & 4 \\
\hline L in search of a new job & & & 3 & & 3 \\
\hline L's inventions & & & & 3 & 3 \\
\hline L's personal webpage & & & 2 & 1 & 3 \\
\hline Switzerland, the Alps as his residence & & 3 & & & 3 \\
\hline $\begin{array}{l}\text { The problem of 'gastarbeiters' in } \\
\text { Moscow }\end{array}$ & & 3 & & & 3 \\
\hline 'Cherkizon' & & & 2 & & 2 \\
\hline Anniversary of Moscow & & & 2 & & 2 \\
\hline Cap & & & 2 & & 2 \\
\hline $\begin{array}{l}\text { L's absence when Moscow region was } \\
\text { on fire }\end{array}$ & & & 1 & 2 & 3 \\
\hline L's conflict with Dorenko & & & 1 & 1 & 2 \\
\hline Moscow ecology & & & 2 & & 2 \\
\hline Terrorism & & & 1 & & 1 \\
\hline Tsereteli & & & 1 & & 1 \\
\hline \begin{tabular}{|l|} 
Total \\
\end{tabular} & 66 & 117 & 120 & 126 & 429 \\
\hline
\end{tabular}

Figure 2. The themes of discussions (absolute frequency of the themes reflected-not percentage).

As Twitter turned out to be the website that reacted to the news most operatively, the most often posted tweets were about Luzhkov's refusal to take part in the Day of Anger, organized by the opposition, and his application for the Latvian residence permit (he applied for it, but Latvian government refused) as well as the British residence permit - these were the latest topics for the posts about the former mayor on Twitter those days (data collected on February 11, 2011). The other most popular opinions manifest, firstly, that criticizing TV programmes (in case the thread that appeared just before the TV programmes about Luzhkov's dismissal is considered) appeared or (later) dismissal happened 
because Luzhkov was not favoured by the government any more, or because it was just a show-off before the upcoming election. Some messages deal with the wording that accompanies Luzhkov's dismissal, especially with loss of confidence and the word 'otreshenie' ('renunciation'), the archaic official term for impeachment.

It was also said that common people will never know the reasons of the conflict. Luzhkov was often compared to V. Matvienko - Mayor of Saint Petersburg at that time (since it is the second largest and quite important city of Russia, and also because it was discussed on Saint Petersburg forum). Speculating about who would become the new mayor as well as about the character of Sergei Sobyanin - who actually became the mayor later - was also quite popular. The five correlating themes considered Luzhkov to be a thief who stole a lot, a rich man, accused him of corruption and preferential deals with his wife, Elena Baturina, or stressed that he deserved criminal conviction. Luzhkov was compared to B. Berezovsky and M. Hodorkovsky, some other former influential people in Russia, who are not in favour any more (M. Hodorkovsky is in prison, while B. Berezovsky died in British political asylum in the UK in March 2013). Moscow architecture (spoilt, new, destroyed), the fancy celebration of the 850th anniversary of Moscow, the problem of traffic jams and building of new roads during his rule, high-tech toilets designed by Luzhkov and called off by Sobyanin (about 100 high-tech toilets, consisting of a toilet cabin itself and the outdoor advertising, were planned to be constructed and used in Moscow streets by Luzhkov, but this project was rejected by Sobyanin), new ways of cleaning snow in Moscow by Sobyanin, and Luzhkov's inventions were discussed as well. Among the points for criticism here were also Luzhkov's attitude towards homosexuals, Luzhkov's conflict with Ukraine and journalist Sergei Dorenko, the problem of 'gasterbeiters' ${ }^{\text {in }}$ Moscow, the destroyed market 'Cherkizon'(Cherkizovsky), Moscow ecology, terrorism, preferences towards the controversial works of architecture by Tsereteli, and Luzhkov's absence when the Moscow region was on fire. The old age of Luzhkov (time for him to retire) was mentioned, as well as his search for a new job (what he was going to do after dismissal). Among other attributes, Luzhkov's personal webpage, bee-keeping, cap, and Switzerland (the Alps) where he has a residence were discussed. Some messages contained positive opinions about Luzhkov, while some were neutral ('I don't care') or just random (concerning some other politician, where Luzhkov was mentioned just occasionally).

Obviously, the results differ from one website to another; that is why afterwards I calculated the percentage of opinions for each discussion (LiveJournal, etc.) and then summed it up to present the whole percentage ratio for all discussions. Thus the results of Twitter, for instance, do not exceed the results of 
the post-dismissal data from www.forum.littleone.ru only because the latter contained fewer opinions than the former. I calculated the percentage in each case separately, not the quantity of opinions summed up together. For example, LiveJournal mainly consists of the posted news, and as far as the search was undertaken on February 11, 2011, these messages mainly contain the news of that day.

\section{JOKES}

Jokes were collected on the Internet from special joke websites, social network media and forums, since the compared material (discussions) is also from the Internet. I searched for the first 100 results for "Anekdoty Luzhkov" (Luzhkov jokes): this approach helped me to find the majority of existing jokes. It is interesting to know that quite many of them were found on the same Saint Petersburg forum www.forum.littleone.ru, which is mainly designed for women (while politics is often considered to be a male dominated business).

In all, I managed to find 65 jokes scoffing at Luzhkov's dismissal (it was usually quite clear which jokes appeared after the dismissal, because they scoffed at the dismissal itself); it means that this event was significant for the inhabitants of Russia; otherwise it would not have been manifested that much in folklore. The overall number of jokes relating to his rule and dismissal was nearly 150, and if we take into account that Luzhkov had been mayor for eighteen years, this fact is of fundamental importance: people created as many jokes within half a year after his dismissal as during the 18 years of his rule. Thus, again, there is no question that this event became significant in society and, consequently, also in folklore.

I have to admit that in some cases the texts collected could hardly be called jokes in the traditional meaning; they were rather humorous poems. As the users or the editors of the website had put them into the category of jokes, this emic perspective made me take them into consideration as well.

All in all, there were 29 categories of jokes I considered: cap, application for the British residence permit, etc.

Finally, I compared the percentage of different themes in the jokes to the same percentage in discussions. 


\section{IS FOLKLORE THE MIRROR OF SOCIETY?}

My aim now is to prove or refute the hypothesis declared at the beginning: if folklore reflects what is going on in society, this would indicate that the main themes that are interesting for people in the discussions will be comparable to the main themes of the jokes.

The table below presents the results of comparing the percentage ratio of the main joke themes to the main discussion themes.

\begin{tabular}{|l|c|c|}
\hline & $\begin{array}{c}\% \\
\text { of opinions }\end{array}$ & $\begin{array}{c}\text { \% of jokes } \\
\text { after dismissal }\end{array}$ \\
\hline The refusal to take part in the Day of Anger & 12.8 & 0.0 \\
\hline $\begin{array}{l}\text { L was not favoured by the government any more } \\
\text { (there was a conflict) }\end{array}$ & 8.2 & 10.7 \\
\hline L compared with Matvienko & 6.1 & 0.0 \\
\hline L is a thief who stole a lot & 5.6 & 7.4 \\
\hline Ideas about who will become the new mayor & 5.1 & 0.0 \\
\hline Application for the British residence permit & 4.9 & 2.5 \\
\hline Moscow architecture (spoilt, new, destroyed) & 4.9 & 2.5 \\
\hline Application for the Latvian residence permit & 4.7 & 3.3 \\
\hline Bee-keeping & 4.2 & 7.4 \\
\hline Comparison with Sobyanin & 3.5 & 1.7 \\
\hline $\begin{array}{l}\text { L as a very rich man (L is rich enough to live well } \\
\text { further on) }\end{array}$ & 3.5 & 3.3 \\
\hline Criminal liability of L & 3.3 & 9.1 \\
\hline Elena Baturina & 3.0 & 10.7 \\
\hline TV broadcasts were ordered by the government & 3.0 & 4.1 \\
\hline Random remarks & 2.8 & 0.0 \\
\hline Positive opinions about L & 2.6 & 0.0 \\
\hline $\begin{array}{l}\text { Talks about 'otreshenie' (impeachment), 'loss of } \\
\text { confidence' }\end{array}$ & 1.9 & 8.3 \\
\hline The problem of traffic jams & 1.9 & 0.8 \\
\hline $\begin{array}{l}\text { The dismissal is just a show-off before the } \\
\text { upcoming election }\end{array}$ & 1.6 & 0.0 \\
\hline Building of new roads & 1.4 & 0.8 \\
\hline $\begin{array}{l}\text { High-tech toilets designed by L and called off by } \\
\text { Sobyanin }\end{array}$ & 1.2 & 0.0 \\
\hline L's attitude towards homosexuals & 3.2 & \\
\hline
\end{tabular}




\begin{tabular}{|l|l|l|}
\hline New ways of cleaning snow in Moscow by Sobyanin & 1.2 & 0.0 \\
\hline $\begin{array}{l}\text { Common people will never know the reasons of } \\
\text { the conflict }\end{array}$ & 0.9 & 1.7 \\
\hline L's old age, time for him to retire & 0.9 & 1.7 \\
\hline L and Ukraine & 0.9 & 0.8 \\
\hline L compared to Berezovsky and Hodorkovsky & 0.9 & 2.5 \\
\hline Neutral reference & 0.9 & 0.0 \\
\hline L's absence when Moscow region was on fire & 0.7 & 3.3 \\
\hline L in search of a new job & 0.7 & 1.7 \\
\hline L's inventions & 0.7 & 2.5 \\
\hline L's personal webpage & 0.7 & 0.8 \\
\hline Switzerland, the Alps as his residence & 0.7 & 0.8 \\
\hline $\begin{array}{l}\text { The problem of 'gastarbeiters' in Moscow (also } \\
\text { registration, accommodation) }\end{array}$ & 0.7 & 1.7 \\
\hline 'Cherkizon' & 0.5 & 0.0 \\
\hline Anniversary of Moscow & 0.5 & 0.8 \\
\hline Cap & 0.5 & 5.0 \\
\hline L's conflict with Dorenko & 0.5 & 0.0 \\
\hline Moscow ecology & 0.5 & 0.8 \\
\hline Terrorism & 0.2 & 0.0 \\
\hline Tsereteli & 0.2 & 0.8 \\
\hline
\end{tabular}

Figure 3. Comparison of the themes of jokes and discussions (percentage).

Undoubtedly, most of the subjects and facets about Luzhkov's personality and rule listed above (extracted from the internet discussions) are very much reflected in the jokes.

At the same time it is obvious that the reflection should not be taken too literally. For example, the fact that Luzhkov refused to take part in the Day of Anger has an incontestable preponderance over the other points, while jokes remain totally unaffected by this fact. But let me remind that this fact was mainly prevalent in LiveJournal and Twitter, where it was repeatedly posted as one of the daily news on February 10-11. Moreover, it is quite difficult to make the news work in the joke: as there are no really bad habits, criminal news, or other humorous potentialities revealed in it. It could also be that perhaps I just failed to find any jokes on this topic, although they actually exist.

The second popular point is among the most widespread ones in both discussions and jokes. People are of the opinion that the mayor's dismissal was caused 
by the conflict with Vladimir Putin or Dmitri Medvedev, or even both, and, as a result, Luzhkov was not favoured anymore. Since the concrete reason of the conflict was not announced officially, and there were numerous suppositions in the press, sometimes also unbelievable ones, the extreme manifestations of these suppositions and their absurd nature are revealed in the jokes. The jokes show that Luzhkov might have been accused of any trifle just to make him guilty.

В доме престарельх трое дедков обсуждают, кто какие анекдоть больше всего любит рассказывать.

Один:

- Я люблю анекдоть про Штирлица!

Второй:

- А я люблю анекдоты про Ржевского!

Tретий:

- А я больше всего люблю рассказывать анекдоты про Вовочку и Винни-Пуха.

Первыц двое хорол:

- Вот вы, Юрий Михайлович, и допизделись в итоге!

(http://inq-brc.ru/index.php/mesto-na-saite/1595-anekdot-20120504, last accessed on October 2, 2012)

Three old men in the home for aged people discuss who enjoys telling which jokes.

The first: "I like to tell jokes about Stirlitz!"

The second: "I like to tell jokes about Rzhevsky!"

The third: "I like to tell jokes about Vovochka and Winnie the Pooh most of all."

The first two with one voice: "That's how you, Yury Mikhailovich,ended up here!"

(Comments: Yury Mikhailovich - the name and patronymic of Luzhkov. Max Otto von Stirlitz is the leading character in a popular Russian book series by novelist Julian Semyonov and its television adaptation Seventeen Moments of Spring. Stirlitz has become a stereotypical spy in Soviet and post-Soviet culture, similar to James Bond in western culture, as well as the hero of numerous anecdotes. Poruchik (lieutenant) Rzhevsky is a cavalry (hussar) officer, another hero in jokes. Vovochka is also a character in jokes, the Russian equivalent of Little Johnny. Winnie the Pooh here is the allusion to Dmitry Medvedev, the president of Russia: his surname derives from the word 'medved”, meaning 'bear'.) 
The third most popular theme of discussions is the comparison of Luzhkov and Mayor of Saint Petersburg Valentina Matvienko, which is not reflected in the jokes at all. Generally, Matvienko rarely became the butt of humour: there were only few jokes about her, mainly scoffing at her failure to struggle with the consequences of snowfalls and numerous icicles, which caused plenty of injures and property damage in 2010 and 2011. Additionally, if we consider the themes related to Luzhkov, they can hardly be associated with the image of Valentina Matvienko ${ }^{2}$.

On the contrary, the idea that Luzhkov is a thief who stole a lot is revealed more or less equally both in the jokes and in the opinions, as well as the topic of his recommendable criminal conviction, which refers to his supposed bribes and thefts.

Заключённые в новой камере знакомятся.

- Ты за что сидишь?

- В 1990-е лешал Лужкову воровать. A mы?

- В 2000-е помогал Лужкову воровать. A тыз?

- А я и есть Лужков.

(http://www.anekdot.ru/id/471278/, last accessed on 2 October 2012)

The prisoners in the cell get acquainted:

- Why do you do time?

- In 1990 I prevented Luzhkov from stealing. And you?

- In 2000 I helped Luzhkov to steal. And you?

- I am Luzhkov.

Another closely related although less popular topic is the comparison of Luzhkov with Berezovsky or Hodorkovsky. In these jokes Hodorkovsky's character is mainly reproduced as both Luzhkov and Hodorkovsky used to be persons of consequence, very rich and successful, but later they lost their status after a conflict with Putin or Medvedev. Logically, the next stage of Luzhkov's case must be criminal conviction, in the same way as it happened to Hodorkovsky.

Салый короткий анекдот про Лужкова: Лужков - Ходорковсколу: "Миш, подвинься!"

(http://www.anekdot.ru/id/471507/, last accessed on October 2, 2012)

The shortest joke about Luzhkov:

Luzhkov to Hodorkovsky: "Misha, move aside, please!"

Ideas about who will become the new mayor were not reflected in folklore. 
Still another interesting topic is Moscow architecture spoilt, destroyed or rebuilt. It is important to mention that it used to be the most wide-ranging topic in the jokes about Luzhkov before his dismissal, although this is not the subject of this research. But the topic survived even in post-dismissal jokes, although these examples are not so numerous and it is not of paramount importance, as it does not create the punch line really but just serves as one of the minor attributes.

После ударно-доходных годков

Что с собой должен захапать Лужков?

Лену Батурину - женшину в теле,

Кепку, Портфбель и всего Церетели.

(http://www.bibo.kz/stishki/376369-posle-udarno-dokhodnykh-godkovchto-s-sobojj.html, last accessed on October 2, 2012)

After highly profitable years

What should Luzhkov grab when he leaves?

Lena Baturina - a plump woman,

The cap, the briefcase and the whole of Tsereteli.

(This text originally rhymes in Russian.)

The rumour that Luzhkov applied for the Latvian residence permit (which was rejected) and the British residence permit soon after his dismissal can be found in the jokes as well.

Не пустили Лужкова в Ригу, показали Лужкову фбигу, на него послотрели косо, и не стал наш Лужков Лужковсол.

(http://www.anekdot.ru/an/z/c330119;1.html, last accessed on October $2,2012)$

Luzhkov wasn't let to Riga, They gave him the finger, They looked at him askew, And Luzhkov didn't become Luzhkovs.

(This text originally rhymes in Russian.)

The jokes also consider his immigration to Great Britain.

- Лужкову наконец-то дали вид на жительство в Англии.

- Значит, пора объявлять всесоюзный розыск.

(http://www.anekdot.ru/id/492697/, last accessed on October 2, 2012) 
- Luzhkov was finally issued the English residence permit.

- So, it's high time to declare that he is wanted by the state.

The theme of Luzhkov's relationship to Switzerland and Austria is very rare both in jokes and discussions.

Sometimes several of Luzhkov's supposed drawbacks or character traits are revealed in one and the same joke. Bee-keeping as the mayor's hobby is one of the examples illustrating such a situation: the point itself is not the main topic of the joke, but it complements the punch line. The mention of the cap has a similar function. This case may be compared to the ones where the narrator tells a joke, using the speech peculiarities of the hero of the joke (like the ones about Georgians or about Boris Yeltsin); for instance, their accent, or expressions characteristic of them (Shmeleva \& Shmelev 2002). The cap as an attribute characteristic of Luzhkov serves the same purpose. The cap is peculiar for him, thus, he may be easily recognized in the joke even in case his name is not mentioned.

В тридевятом иарстве - тридесятол иарстве жил-был мэр Лужков. И любил он что-нибудь разгонять - то облака разгонит, то гей-парад. А однажды разогнал машину до запрещенной скорости, а его работники ГИБДД остановили и права отобрали. Икак он с нили не заискивал, как ни уговаривал решить вопрос на месте -они протокол составили и штрафб неслабый ему выписали. А потол тихонько на ушко ему и говорят: "А нехрен было, голоббоб ты в кепке, наш парад разгонять."

(http://sadalskij.livejournal.com/246753.html, last accessed on October 2,2012 )

Once upon a time, in the kingdom of Far Far Away, there lived Mayor Luzhkov. He liked to disperse things: sometimes clouds and sometimes a gay pride parade. But once he exceeded the speed limit and the police officers stopped him and revoked his driving license. No matter how hard he tried to fawn upon them, no matter how hard he tried to persuade them to solve this problem on the spot, they drew up a report, imposed a fine and then whispered gently into his ear: "You shouldn't have dispersed our pride parade, you, homophobe in a cap."

Since before Luzhkov's dismissal numerous TV programmes appeared accusing him of bribes, theft, enormous wealth, and corruption, these were also reflected in discussions and jokes. 
В Москве идут похоронь Лужкова. Несут иветь, венки и т. д. Рядол идет небольшая колонна и несёт плакат - () ПО ЗАКАЗУ ОРТ. (http://www.anecdots.su/anecdot/25759/, last accessed on October 2, 2012)

Luzhkov's funeral is conducted in Moscow. People come, carrying wreaths and flowers. A small procession goes by, carrying a poster: "Commissioned by ONT".

(ONT (ORT) is a governmentally controlled TV channel in Russia.)

The theme relating to Elena Baturina is very popular in discussions as well as in the pre-dismissal jokes, while post-dismissal jokes do not often reflect it.

- A кто сейчас Лужкова заленил?

- Ресин!

- А у него жена чел занилается?

(http://www.anekdot.ru/id/471288/, last accessed on October 2, 2012)

- Who took the place of Luzhkov?

- Resin.

- And what does his wife do?

Obviously, positive opinions are hardly reflected in the jokes.

Some other extremely important subjects are traffic jams and immigrants ('gasterbeiter') in Moscow, which Luzhkov was always largely blamed for.

Лето. Москва. Пробка. Машины еле ползут. Вдруг к одной из машин подбегает молодой человек в дорогол костюме и стучит в окно. Мужик опускает стекло и спрашивает: чего, мол?!

Молодой человек взахлеб начинает рассказывать:

- Юрия Михайловича захватили террористы, требуют огролный выкуп! Неледленно! Времени вообще нет, иначе обешают облитьлэра бензинол и сжечь! Вот, решили пройтись по машинал - кто сколько даст?

Мужик (задулавшись):

- Ну, я литров пять могу дать!

(http://www.tnu.in.ua/forum/archive/index.php/t-410-p-2.html, last accessed on October 2, 2012)

Summer, Moscow, a traffic jam. The cars hardly crawl along. Suddenly a young guy wearing an expensive suit runs up to one of the cars and knocks at the window. The man in the car opens the window and asks what the guy needs. The latter starts telling effusively that Yury Mikhailovich was captured by terrorists, who hold him for ransom. No time at all, 
otherwise they promised to pour gasoline over him and burn him down. That's why the mayor's friends decided to ask people in the nearest cars if they could give something.

After thinking for a while, the man says: "Well, I could give five litres."

Nevertheless, the topics relating to traffic jams and immigrants become practically the least important jokes relating to Luzhkov's dismissal, although previously they used to be the most significant in the joke cycle about Luzhkov.

One of the migration-related problems was the institution of 'propiska', which Luzhkov was often vituperated for. This is reflected in the following joke, where the boot turns out to be on the other foot: Luzhkov himself takes the place of those who suffered from this practice.

Сразу после отставки Лужкова планируется отселить его с Батуриной за 101-й километр, потолу как вряд ли они пройдут московскую регистрацию. Понаехали тут, понилаешь, лилита хренова! (http://www.anekdot.ru/id/470360/, last accessed on October 2, 2012)

After Luzhkov's dismissal it is planned to lodge him together with Baturina behind the 101st kilometre of Moscow, as they will hardly get Moscow registration. Come back where you belong, lousy limita!

(Limita - people within the propiska quota, also known as limitchiks (limitchiki), from the Russian word 'limit' for 'quota'. Propiska quota was the system of residential permits and registration in major cities of the Soviet Union. Later the word 'limita' lost its initial meaning and is now used for those who come to the biggest cities of Russia from other cities or countries to work and live.)

A similar thing happens in the 'homophobia' topic: in the joke Yury Luzhkov turns out to be in the opposite position if compared to the previous one: here he divorces Baturina (who used to be one of the main characters in Luzhkov cycle) and becomes a homosexual although he used to be a homophobe.

Как стало известно Юрий Лужков развелся с Батуриной и переехал жить к Длитрию Харатьяну. Юрий Михайлович признался что в свое вреля женился на Батуриной из-за внешнего сходства с его возлюбленннылм. Прежний статус не давал возложности открыто быть с любильл. Теперь же когда ничто больше его не удерживает он рад что может открыто заявить миру о своих чувствах. И впервые извинился за гей-парад: "Я дулаю дорогие вы меня пойлете и простите. Теперь если разрешат я выйду с вали, пацанчики!" (http://www.anekdot.ru/id/474761/, last accessed on October 2, 2012) 
As reported, Yury Luzhkov divorced Baturina and moved to Dmitry Haratyan's place. Yury Mikhailovich confessed the fact that he had married Elena Baturina because she had resembled his lover. The previous position of mayor did not let him hook up with his sweetheart. Now nothing keeps him from his love and he is happy that he can declare his intimate feelings to the world. For the first time he asked to excuse him for the pride parade: "I think, my dear, you understand and forgive me. If they allow the next pride parade I will go out with you, you naughty boys!"

Two other closely related themes are the formulations for the mayor's dismissal ('otreshenie') and loss of confidence ('utrata doveriia') and the opinion that the dismissal per se was just a show-off before the upcoming election, to pretend that the government dismisses those who deceive people or do not keep their promises. The former theme became very popular in folklore, probably because the formulation itself was not quite usual for the recent history of the country and at the same time it did not really reveal the reason behind it. Meanwhile, the topic is closely connected with the idea that an unknown conflict happened between the government and the mayor, which was also mentioned above.

Разговаривают два гаишника.

- Сльцшал новость? Президент Лужкова в отставку отправил изза какой-то ерундьц!

- А в чел он провинился?

- Да доверенность какую-то потерял.

(http://anekdotov.net/anekdot/all/akojtoerundyavchemonprovinilsjadadoverennostkakujutopoterjal.htm, last accessed on October 2, 2012)

Two GAI (State Automobile Inspectorate) officers talk:

- Have you heard the news? The president dismissed Luzhkov because of a trifle!

- What is his fault?

- He lost some kind of warrant...

(In Russian the words 'doverennost” ('warrant') and 'doverie' ('confidence') are paronymous, and the pun is used in the joke.)

It is also quite natural that the new mayor Sobyanin is now compared to the previous one, although he does not appear in the jokes so often.

Among the latest (as of February 2011) news in discussions was, firstly, that Sobyanin rejected the project of high-tech street toilets once provided by Luzhkov, and secondly, that the new mayor changed the methods of cleaning the streets in Moscow during winter. As a result, many people reported that they 
fell and hurt themselves in icy streets. I failed to find jokes connected with this particular news. The popularity of the latter on the web may be explained by the specific sources - Twitter and LiveJournal, which tend to post mainly news, and this popularity is temporary, greatly restricted in terms of time. The same applies for Luzhkov's personal webpage: he said that he was ready to develop his personal webpage although his life was transparent for everybody even without the webpage. The news circulated on the internet for several days only and probably it was not important enough to become the basis for new jokes.

Homophobia is another issue Luzhkov was always blamed for not only in the media, but in folklore as well.

The topics of Cherkizon (the well-known Moscow market that was closed down when Luzhkov was in power) and terrorism are rarely mentioned on the chosen websites and were not found in the jokes either.

Furthermore, there are a few jokes about Luzhkov trying to find a new job another attempt to show that now he is an ordinary person with no privileges.

Ознаколившись с бборлулировкой последнего приказа в трудовой книжке Лужкова, Елена Батурина отказала елу в приёле на работу.

(http://www.bibo.kz/anekdoti/375665-oznakomivshis-s-formulirovkojjposlednego-prikaza.html, last accessed on October 2, 2012)

After looking through the formulation of the last entry in Luzhkov's service record, Elena Baturina refused to employ him.

Finally I should mention the problem that Luzhkov was often blamed for: when Moscow region was on fire in August 2010, he was having a holiday in Austria. Only one joke was found about it, and the main topic is tangibly transformed.

Сенсаиия! Разгадана причина смога над иентральной Россией. Это во вреля “отпуска” мэра его коланда, почувствовав недоброе, жгла колпролат за 18 лет.

(http://www.bibo.kz/anekdoti/80769-pro-kompromat.html, last accessed on October 2, 2012)

Sensation! The reason for the smog over central Russia has been found! It is that during Luzhkov's holiday, the mayor's team, for fear of trouble, set on fire the discrediting evidence found about him from the past eighteen years. 


\section{CONCLUSIONS}

The widespread opinion that folklore is the reflection of society was tested here through the comparison of the opinions expressed by people and their quantitative representativeness in the jokes about the same event. It is clear that the jokes sometimes possessed several themes, in which case I tried to take all of them into account without underlying the only one which was the most important for the punch line, since all of them contributed to it to a smaller or greater extent. In the same way, none of the opinions found on the web may be considered as the most or the least important, since they create the image as a whole.

My initial expectation was to achieve more straightforward results which could confirm the declared theory. Even though there is much correspondence between the opinions and the jokes, the results showed that folklore is quite selective, and often reveals the issues that are in some way sympathetic to the genre. In addition, some facts are not easy to be ridiculed, for example, it is hardly possible to make jokes about the positive characteristics of a hero.

Luzhkov has always been an important figure in the jokes, since he was the mayor of the Russian capital. But most of the topics before and after his dismissal are quite different. As a whole, the jokes switch from being the bearers of separated ideas (here I mean the jokes told about Luzhkov before the dismissal) to being the units containing several themes within them (after the dismissal). They tend to summarize the opinions about Luzhkov's activities. That is why we have numerous examples where Luzhkov is not just depicted as the 'builder' as he used to be, but where his more or less complex image is provided, including several themes. Thus the character becomes more complicated. The jokes now tend to draw a kind of conclusion about most of Luzhkov's features as well as his rule.

Jokes about Luzhkov still appear, even though he is not that important political figure any more. People hold him in remembrance because the result of his rule, namely, the appearance of modern Moscow, still exist. There is no doubt that it changed considerably within these eighteen years and since people are greatly afraid of changes in general, it is only natural that they are reflected in jokes. Jokes are often used to accumulate and then voice the indignation concerning novelties. That is why all troubles that Luzhkov went through lately are savoured in the jokes; this is the form of revenge and consolidation as well. People are happy to know that the boot is on the other foot now; he who used to be rich, respectable and lucky is in an unenviable position today: the jokes even usher him to move away from Moscow since he does not have his registration, 
or depict him as a homosexual. The image of the former mayor now occupies an oppositional place if compared to his principles or decrees he issued in the past.

Often the jokes are told in the form of news as far as it is the main form of the media that talked about him in the first place, and thus the jokes acquire a formal similarity of appearance with the news, possessing the parenthetical words and clauses like "it has been reported". Researchers have claimed that the purpose of these jokes is to aim at the aggression in the mass media and the power it has (Simons 1986; Smyth 1986).

Finally, the jokes researched are told not only about Luzhkov. For instance, the joke about three people in a prison cell discussing what they were punished for is also widely told about the Belarusian president Alexander Lukashenko, and this is not the only example.

Obviously, this topic deserves further research of different material as far as reactional humour turns out to be something more complicated than just a mere reflection of life.

\section{ACKNOWLEDGEMENTS}

This research was supported by the Doctoral Studies and Internationalisation Programme DoRa, ESF grant No. 8149. I would like to thank Jeana Jorgensen for reviewing the article and offering suggestions. Any remaining errors are my own.

\section{NOTES}

1 A guest worker. The word was loaned from German and is widely used in Russian to define the immigrants (especially from the former Soviet part of Asia) coming to work in the big Russian cities.

${ }^{2}$ Nevertheless, the jokes mentioning both figures started to appear later, when Matvienko became the hero of news: she left the position in Saint Petersburg and became the Chairman of the Federation Council of the Russian Federation: After reading about Luzhkov's fortune of 10 milliards and Matvienko's fortune of 3 milliards in press, the university entrants of Moscow State University demanded from the governing body of the university to open new faculties: of bee-keeping and laser icicle-cutting. 


\section{REFERENCES}

Alekseevsky, Mikhail 2010. Anekdoty ot Ziuganova: fol'klor v sovremennoi politicheskoi bor'be. [Jokes from Zuganov: Folklore in Contemporary Political Struggle.] Antropologicheskii forum online, No. 12, pp. 1-36.

Arkhipova, Aleksandra 2001. Anekdot v zarubezhnykh issledovaniiakh XX veka. [The Joke in Foreign Research of the 20th Century.] Zhivaia starina, No. 4, pp. 30-31.

Arkhipova, Aleksandra 2009. Traditsii i novatsii v anekdotakh o Putine. [Traditions and Innovations in the Jokes about Putin.] Antropologicheskii forum, No. 10, pp. 181-251.

Arkhipova, Aleksandra 2012. Anekdoty o Putine i vyborakh 10 let spustia, ili Est' li fol'klor Snezhnoi revoliutsii'? [Jokes about Putin 20 Years Later, or does the Folklore of "Snow Revolution" Exist?] Antropologicheskii forum online, No. 16, pp. 208-252.

Arkhipova, Aleksandra \& Mel'nichenko, Mikhail 2008. Poluchite protsenty za Vash kapital!: K voprosu ob evoliutsii sovetskogo politicheskogo iumora. [Draw Interest from your Capital! About the Evolution of Soviet Political Joke.] Gabrieliada. K 65-letiiu G.G. Superfina. [Gabrieliada. Dedicated to the 65th Anniversary of G.G. Superfin.] http://www.ruthenia.ru/document/545433.html, last accessed on October 2, 2012.

Laineste, Liisi 2008. Post-Socialist Jokes in Estonia: Continuity and Change. Dissertationes Folkloristicae Universitas Tartuensis. Tartu: Tartu University Press.

Oring, Elliott 1987. Jokes and the Discourse on Disaster. The Journal of American Folklore, Vol. 100, pp. 276-286, doi:10.2307/540324.

Shmeleva, Elena \& Shmelev, Dmitrii 2001. Politicheskii anekdot: tipy kommunikativnykh neudach. [Political Joke: Types of Communicative Failures.] Trudy mezhdunarodnogo seminara Dialog' 2001 po komp'iuternoi lingvistike i ee prilozheniiam. [Proceedings of the International Seminar Dialogue 2001 on Computer Linguistics and its Applications.] http://www.dialog-21.ru/materials/archive. asp?id=6802\&vol=6077 \&y=2001, last accessed on October $2,2012$.

Shmeleva, Elena \& Shmelev, Dmitrii 2002. Russkii anekdot: Tekst i rechevoi zhanr. [Russian Jokes: Text and Speech Genre]. Moscow: Iazyki slavianskoi kul'tury.

Simons, Elizabeth 1986. The NASA Joke Cycle: The Astronauts and the Teacher. Western Folklore, Vol. 45, No. 4, pp. 261-277, doi:10.2307/1499821.

Smyth, Willie 1986. Challenger Jokes and the Humor of Disaster. Western Folklore, Vol. 45, No. 4, pp. 243-260, doi:10.2307/1499820. 